\title{
The Global Financial Crisis Impact on Ethnic Diversity of Sri Lanka Boards
}

\author{
Nirosha Hewa Wellalage (Corresponding author) \\ Department of Finance, University of Waikato Management School \\ Hamilton, New Zealand \\ Tel: 64-(7)-838-4466 ext 6687 E-mail: nirosha@waikato.ac.nz
}

Stuart Locke and Frank Scrimgeour

University of Waikato, Hamilton, New Zealand

$\begin{array}{ll}\text { Received: January 5, } 2012 & \text { Accepted: January 26, } 2012 \quad \text { Published: June 1, } 2012 \\ \text { doi:10.5296/ajfa.v4i1.1243 } & \text { URL: http://dx.doi.org/10.5296/ajfa.v4i1.1243 }\end{array}$

\begin{abstract}
This study investigates the link between ethnic minority directors and agency conflict in Sri Lankan listed companies during a global financial crisis. Due to social and economic pressures in recent decades, ethnic minorities now make up a larger proportion of directors on corporate boards in Sri Lanka. In addition, the global financial crisis has increased demand for boards to strengthen their ethnic diversity in workplaces. This study shows that while Sri Lankan boards increased the number of ethnic minority directors during the global financial crisis, heterogeneous boards increased company agency costs. This evidence provides insights for governments and policy makers as they consider board ethnic diversification in an emerging and highly uncertain environment.
\end{abstract}

Keywords: Ethnic minority directors, board structure, agency costs, Sri Lanka JEL Classification: G34 


\section{Introduction}

The large corporate failures that occurred at the beginning of the $21^{\text {st }}$ century may have damaged confidence in many economies. Fraud and bribery were seen as contributing to company collapses. Europe was significantly impacted by the global financial crisis in 2007 . It affected the Asian region in late 2008 and led to the realisation that if boards wanted to improve their corporate governance practices they needed to diversify their composition. As a result, corporate board structure has been debated extensively and subsequently improved in several countries. Legislation includes the Higgs Review (2003), and corporate governance best practice in Sri Lanka (2008) which recommended more recruitment of non-executive directors from diverse backgrounds, including ethnic minorities, to maintain board independence.

According to Mattis (2000), boards need to represent the diversity of the firm's customer base and labour force. If a board discriminates against a specific group, especially ethnic minorities, this implies arbitrage possibility, because underutilised valuable human capital (Gregoric et al., 2009). Therefore, a well-diversified board with many ethnic minority directors can be instrumental for company success in financial hard times, especially in a global financial crisis. The global financial crisis has increased demand to strengthen board ethnic diversity in the workplace, because during the hard times company willingness to follow business ethics which are watching by stakeholders due to less incline to commit misconduct. The influence of different viewpoints of diversified directors can improve firm creativity, especially in a complex and competitive environment (Macfarlane et al., 2010). However, Hill (2004) says due to the global financial crisis and lack of financial resources, few women and minority ethnicities are recruited to boards across all industries. In addition, there is a high financial cost involved in recruiting, co-ordinating and accommodating diversified employees and boards (Hambrick et al., 1996). This may be another reason for less board ethnic minority recruitment in a global financial crisis. Ethnic minorities were underrepresented on corporate boards in early years, but that began to change in the late 1990s (Farrell \& Hersch, 2005). However, that change has been slow. Brammer et al. (2007) show from their 463 study sample of UK listed firms, only $0.2 \%$ have non-white board directors.

Homogenous board "group thinking” can be harmful, especially in a global financial crisis, because board members thinking patterns are too similar in decision-making processes (“Corporate Governance”, 2011). Therefore, corporate boards need to be more diversified to provide greater knowledge, creativity and competitive edge to a company. The competitive global market provides a compelling business argument for more diverse boards with minority directors. If the homogeneity of corporate boards raises significant ethical, economic and social issues, then a more diverse board with increased ethnic minority representation may help solve that situation. Board internationalisation is another reason for adding more non-national directors (minority directors). Due to globalisation, in 2009 European boards averaged 23\% non-national directors, an increase of $11 \%$ since 2008 (“Boards in Turbulent Times”, 2009). 
To overcome the influence of the global financial crisis, most emerging economies try to strengthen rules and regulations. Due to high uncertainty and weak legal regulations, most of the emerging markets have faced recession in recent years. Through board diversity, most developed markets try to maximise their profit in financial hard times, because board diversity increases board monitoring. Emerging markets' institutional structures and practices are different from developed markets so applying the same board diversity argument to emerging markets remains doubtful.

Though there have been studies of ethnic diversity on top management (Marimuthu, 2008; Roberson \& Park, 2007) and its effect on firm financial performance, this is the first study to especially concern itself with board ethnic diversity during a global financial crisis period. Moreover, this study shows board ethnic diversity impacts on firm principal-agent (PA) and principal-principal (PP) agency costs. Although there have been contemporary studies on board diversity and PA agency costs, PP agency costs and board ethnic diversity relationship has not been widely discussed in prior literature. This is first study to provide evidence of board ethnic diversification and its impact on PA and PP agency costs in emerging market firms. Additionally, studies on board ethnic diversity present reverse causality and endogeneity issues and due to this, it is still unclear whether more successful firms have greater capacity to adopt more ethnic diversity or if more ethnic diversified boards lead to better performance. However, this study controls potential endogeneity effect in regression technique.

The next section reviews prior research, develops the hypotheses and is followed by discussion of data, variables, methods and procedures used for this empirical study. The results and conclusion then follow.

\section{Literature Review}

Cultural differences, ethnicity and demographic differences are known to affect business practices, organisational structure, account disclosure and audit practices (Haniffa \& Cooke, 2002; Yatim et al., 2006). A UK-based study finds that many institutional investors prefer diversified boards with more female or minority directors (Brammer et al., 2007). This may be because minority directors promote more effective global relationships, and ethno-cultural diversity makes corporate leaders more sensitive to other cultures, especially in business internationalisation (Wang \& Clift, 2009). However, based on the theory of stereotype threat, majority members may underestimate minority contributions (Frances \& LMartins, 1996) and ethnic minority directors may not be able to perform well in the workplace, especially in an economic downturn.

Carter et al. (2003) study Fortune 1000 companies and find companies with two or more ethnic minority board directors perform better than companies with no ethnic minority directors. Erhardt et al. (2003) using 127 US large companies, suggest a positive association between ethnic minority directors' percentage and financial performance of the company. This may be because directors from different ethnic backgrounds have a broader view and a large pool of information to contribute to the decision-making process. Similar to the above findings, Carno and Chen (1998) posit ethnic diversity of board directors increases the 
decision-making quality of the company and strategic analysis. Further, introduce ethnic diversity on corporate board leads to increase competitive advantage and strategic analysis ability of the firm. Ethnic diversity increases board independence, because people with different cultural backgrounds raise more questions than do a homogenous group of directors (Carter et al., 2003; Laughlin, 1992).

In emerging market findings, Haniffa and Cooke (2002) find the ethnic background of directors is significantly related to company financial performance. Using Malaysian top 100 non-financial companies listed on the stock exchange over a six years, Marimuthu (2008) explains that ethnic diversity enhances firm financial performance. Furthermore, he explains a one unit increment of board ethnic diversity leads to an increased six units in firm performance. Johnson \& Mitton (2003) and Gomez \& Jomo (1997) explain Malaysian ethnic-favoured firms appear to have poor corporate governance practices and higher agency costs due to being ethnically favoured and politically connected.

Board independence is critical for boards to function and to align the interests of shareholders. In other words, more ethnically diversified boards are more independent and reduce agency conflict. However, a diverse top management team leads to conflict of interest and increases the agency costs, especially in high uncertainty markets. Using 227 Malaysian public listed companies, Foo \& Zain (2010) find that high ethnic minority director levels increase information asymmetry in Malaysian firms. Thus, increasing ethnic diversity in the board room could have adverse consequences for the company. Davidson (2002) argues that women and minority workers are disadvantaged compared to their white male counterparts and for this reason the minority may underperform. This may be based on the theory of tokenism, which explains minority members face difficulties performing to their potential in the workplace because the tokens are forced into stereotypical categories defined by the dominants (Reskin et al., 1999). Moreover, based on the stereotype threat, research indicates that minority groups underperform in the workplace, because they feel they are being judged as group rather than individuals (Spencer et al., 1999; Steele \& Aronson, 1995).

\subsection{Agency costs}

Costs associated with a lack of goal congruence between two parties were brought to the fore by Ross (1973) and were further explored by Jensen \& Meckling (1976). These costs are often referred to as agency costs and can occur between a principal and agent (PA) and also between principal and principal (PP). A PA problem arises when agents pursue their own goals rather than the goals of the principal. It is the result of conflicting interests among managers and owners and asymmetric information (Chrisman et al., 2004). The PP situation is best described as a firm with one large shareholder and a fringe of small shareholders (Villalonga \& Amit, 2006). In such a firm, the traditional PA agency conflict is alleviated due to the large shareholder's greater incentives to monitor the manager, but, a second type of conflict emerges as large shareholders exercise their substantial control and influence over firm matters and, as agency theory suggests, they have incentives to consume the firm's resources at the expense of the minority shareholders (Anderson \& Reeb, 2004).

Due to weak rules and regulations and a weak organisational and institutional environment, 
PA agency costs may prevalent in Sri Lanka. On the other hand, due to the fact that more than $64 \%$ of Sri Lankan-listed businesses are family firms, family or individual expropriation can be common in Sri Lanka. Therefore, PA and PP agency costs compound issues in the Sri Lankan market.

\subsection{Ethnic Minority in Sri Lankan Boards}

Sri Lanka, a lower- middle-income island located in the Indian Ocean, has made considerable progress in human development, such as literacy and life expectancy. There is nothing in the languages or religious systems in Sri Lanka that officially promotes the social segregation of their adherents; however, based on language and religion, there are four major ethnic groups in Sri Lanka. The Sinhalese are the largest group, representing approximately $74 \%$ of the total population. The Tamils are the major ethnic minority and make up $18 \%$ of the population.

Around the world companies are facing increasing pressure to appoint ethnic minority senior officers and management. Many recent proposals of governance reform explicitly stress the importance of ethnic diversity in the boardroom. However, this is significantly high in Sri Lanka compared to the US and other developed countries. Figure 1.1 shows minority directors in Sri Lankan companies since 2006 (excluding the banking and finance sector). This figure is roughly constant and has stayed around $40 \%$ since 2006 . However, a US based study shows that in 2010 only 9\% of directors from S \& P 500 companies are of ethnic minority ("Hot Topics", 2011). Notably, this figure is down from 12\% in 2008 and 2009 and $11 \%$ in 2007 . This shows the ad-hoc manner of ethnic minority recruitment in US boards. Nevertheless, figure 1.1 clearly shows minority board representation has increased in Sri Lanka since 2006. This may be due to the following reasons. The first major reason is corporate governance reform in Sri Lanka (2008) has promoted board independence. Based on agency theory, boards that have more ethnic minority directors may be more effective in monitoring on behalf of shareholders. Therefore, companies may select non-executive directors form ethnic minority groups. The second reason is the global financial crisis, which resulted in Sri Lankan firms increasing board diversity through ethnic minority directors. According to Hoffman \& Maier (1961), it may be that group diversity increases problem solving capacity in Sri Lankan firms in financial crisis. Moreover, an ethnically diversified board may have "signalling value" for Sri Lanka. Therefore, Sri Lankan companies add more ethnic minorities in a global financial crisis. Another reason is that after the civil war, the majority of businesses expanded into Northern and East areas of Sri Lanka, which have more ethnic minorities. Therefore, after 2009, ethnic minorities engage more in investment and they became board directors and hold more shares. 


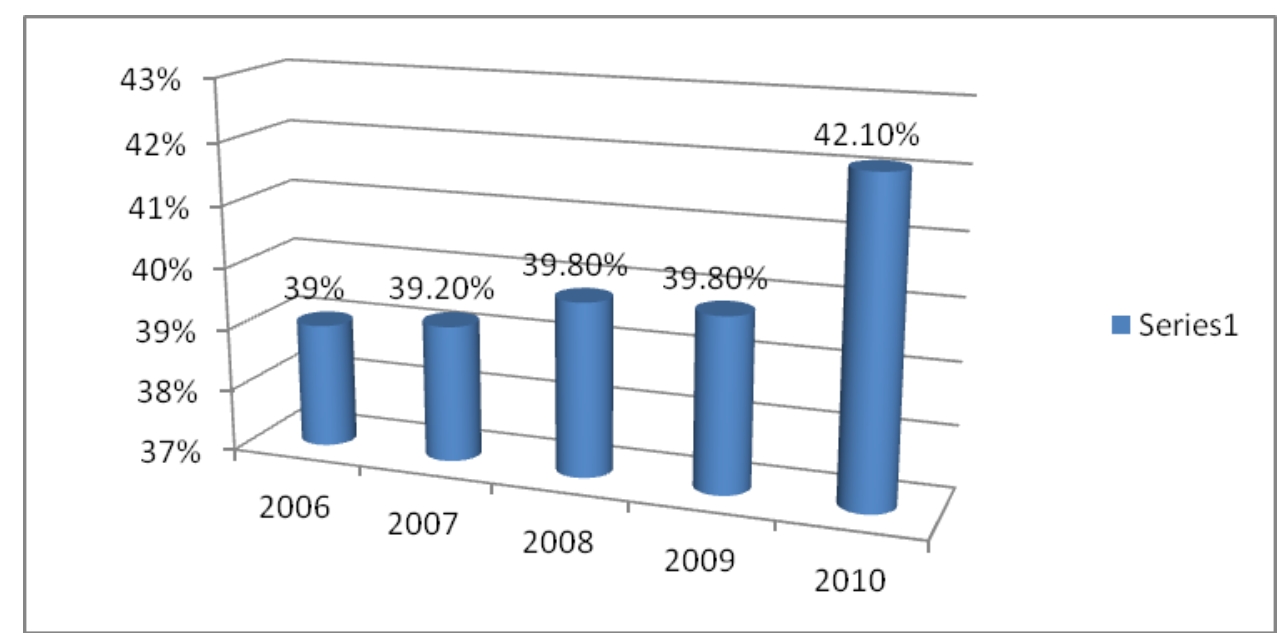

Figure 1. Ethnic minority representation in Sri Lankan listed companies’ boards

Based on social psychology, Zander (1979) finds that group loyalty depends on similarities of group members. Further, Adams \& Ferreira (2002) explain this kind of trust is specially required in high environmental uncertainty. This finding is consistent with Kanter (1977) who explains that in a high uncertainty environment, costs are created when adding more ethnic minorities. Also based on social choice literature, Arrow (1951), explains collective decision making increases the cost of communication. This is because conflicts of interest may increase in heterogeneous groups. Therefore, adding more ethnic minority directors in Sri Lankan firms, especially in a global financial crisis, needs further attention.

\section{Methodology}

\subsection{Data}

The sample for the panel data analysis embraces non-financial firms listed on the Colombo Stock Exchange (CSE) before and during the recent global financial crisis. Like other Asian countries, Sri Lanka felt the global financial crisis later than Western countries (Rathnayake, 2009). Based on stock market price index changes, this study identified the global financial crisis effect in Sri Lanka in the last quarter of the 2008 financial year. Therefore, using the year 2008 as a benchmark, this study use two sample of data sets. That is, the global financial crisis data set (2009) and the before the crisis dataset (2007). The data is gathered from two CSE publications (Fact Book 2008 and Handbook of Listed Companies 2007) and individual companies' audited annual reports. As at 2009, the CSE had 203 listed non-financial companies representing 19 business sectors. From that 203, four companies did not provide all relevant data. Instead of choosing a random sample, this study includes the remaining 199 companies.

Dependent variable- Following Ang et al. (2000) and Singh \& Davidson (2003), the assets utilisation ratio is used as a PA agency proxy for this study. Assets utilisation is defined as total sales divided by total assets. PA agency cost is inversely related with the assets utilisation ratio. John \& Knyazeva (2006) explain that when firms have poor governance they may have a higher dividend payment policy. Moreover, DeAngelo \& Skinner (2004) find that 
firms with high agency conflicts are more likely to pay dividends than firms with fewer agency conflicts. Therefore, this study employed dividend payout ratio as proxy for PP agency costs. Similar to Faccio et al. (2001), dividend payout ratio is defined as total dividend payment divided by net sales.

Explanatory variables- As proxies for the ethnic diversity of the board of directors, two variables were used. The first variable is the percentage of minority directors (MINO) on the board. This is calculated as the number of minority directors divided by the total number of board directors. The second variable is dummy variable (DMINO), which takes a value of 1 when at least one minority director is present on the board and 0 otherwise. The following variables are included in this study. Board size (BOARD), defined as logarithm of the total number of directors. OWNER is dummy variable, which takes a value 1 if company is local, otherwise 0 . Leverage is calculated as the ratio of total debts to total assets (DEBT), firm size (LNSALES) is defined as logarithm of the total sales of the company. As a performance measure, the return on assets (ROA) and firm maturity (AGE) are measured by the number of years operating in the industry.

Descriptive statistics for all variables are presented in Table I.

Table 1. Descriptive statistics

\begin{tabular}{llllll}
\hline Variable & Obs & $\begin{array}{l}\text { Mean- } \\
\text { Crisis }\end{array}$ & $\begin{array}{l}\text { St. Dev- } \\
\text { Crisis }\end{array}$ & Mean-Health & $\begin{array}{l}\text { St. Dev- } \\
\text { Crisis }\end{array}$ \\
\hline PA & 197 & .8642145 & .7122445 & .872132 & 0.738975 \\
PP & 197 & .125082 & .5089497 & .093886 & 0.365995 \\
MINO & 196 & .3984105 & .2704389 & .395126 & .2641468 \\
DMINO & 196 & .877551 & .3286431 & .873684 & .33384 \\
BOARD & 194 & 7.309278 & 2.001869 & 7.25883 & 1.954178 \\
OWNER & 199 & .567 & .4966258 & .5678939 & .496626 \\
LNSALES & 197 & 13.53964 & 2.237536 & 13.36782 & 2.238855 \\
LNDEBT & 199 & .2336866 & .19302 & .3099313 & 0.193580 \\
ROA & 198 & .0249774 & .0776468 & .034171 & 0.082983 \\
LNAGE & 197 & .1680019 & .758504 & 0.153698 & 0.700688 \\
\hline
\end{tabular}

Table 1 indicates descriptive statistics of variables. Statistics for each variable in the global financial crisis period and economically stable period are reported separately. Overall results indicate there is no significant difference in board and firm characteristics in these two time periods. However, results shows that slightly higher PA and PP agency costs occur in a global financial crisis. This may be because a global financial crisis leads to high information asymmetry problems. This is confirmed by Renaud (2003) who explains that during the crisis and due to a lack of limited liable information, agency conflict increases in emerging economies. Considering the explanatory variables, results indicate that firms employ more minority directors in recession time. Additionally, the DMINO variable indicates that in a global financial crisis Sri Lankan listed firms try to recruit at least one minority director. It 
may be firms believe that through a diversified board with a full range of talent and expertise, managers can improve firm performance in an economic downturn ("Corporate Governance", 2011). It may also be that in a global financial crisis boards with more ethnic minorities equip a company better to serve customers from different cultural backgrounds (Fields, 2011). Further descriptive statistics indicate that in a global financial crisis board size is slightly higher than in non-financial crisis periods. This may be due to more ethnic minority recruitment in financial crisis time, and so board size may increase along with board diversity.

Considering control variables, except firm debt level, other variables' mean values do not show significant difference between global financial crisis and non-financial crisis time. However, firms DEBT indicates that companies acquire less debt in recession. This may be because tighter monitoring during a recession leads to a decline in accessing bank debt (Borensztein \& Lee, 2002). This may be significant in Sri Lankan markets because banks remain the main provider of debt (Colombage, 2007).

Figure 1.2 further elaborates PA and PP agency costs variables and board ethnic diversity ${ }^{1}$ variable behaviour in global financial crisis and non-global financial crisis periods in Sri Lankan listed firms. A kernel density graph indicates there is similar pattern of PA agency costs distribution during a global financial crisis and financially healthy times. However, it clearly shows companies do not pay as much in shareholder dividends during non-crisis times, and are more likely to pay more dividends during a financial crisis. This may be because in an economic recession firm growth is slower and to avoid agency conflicts firms pay-out their excess cash flows as dividends. In economically stable times when firm growth is stronger, excess cash flows are used for further investments.

The ethnic diversity density graph shows firms to be more concerned about board diversity in financial crisis periods than in stable economic times. It may be firms try to increase financial performance through board diversification. Diversified board members levels of innovation and creativity help to drive high company performance even in a financial crisis.

\footnotetext{
${ }^{1}$ Board diversity (DIVERSITYT), which is measured by Blau Index. The Blau index is calculated by $1-\Sigma .1 p^{2}$ where $p$ is the proportion of board members in each category and $n$ is the total number of board members. The Blau index value range for diversity is 0 from 0.5 , which can be achieved only when a board has equal numbers of minority and majority board directors.
} 

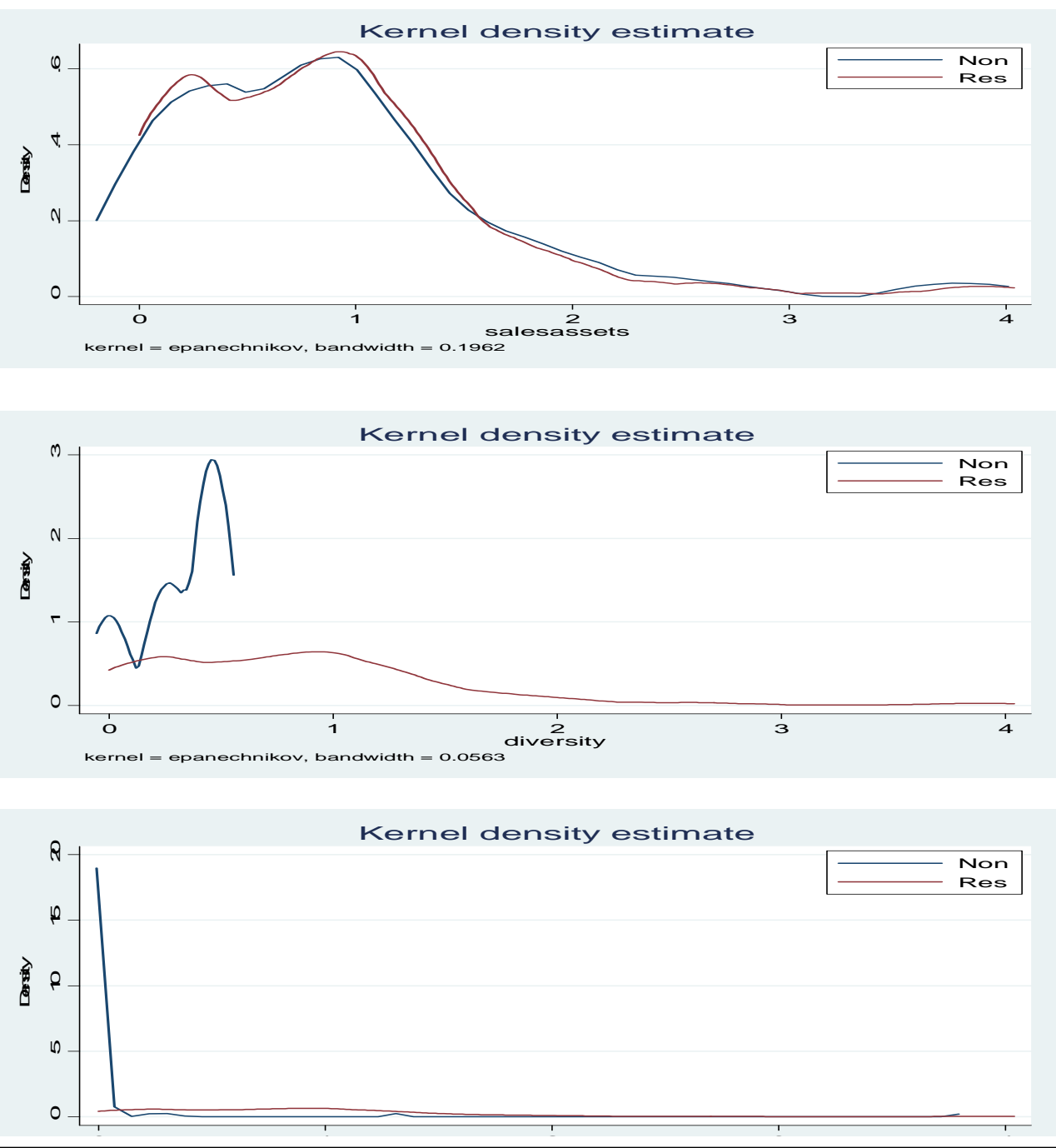

Figure 1.2: Kernal density of variables

\subsection{Method}

Panel data analysis is the most efficient statistical method, widely used in econometrics and social science (Madalla, 2001). The panel data structure allows for taking into account the unobservable and consistent heterogeneity, which are specific features of each company. However, panel data also give rise to statistical problems in regression analysis. In particular, it is important to determine whether there are fixed effects present in the variables. This study uses Hausman's specification test to differentiate between random and fixed effects of 
variables $^{2}$.

On the other hand, board diversity studies have become more complicated in recent years due to their causality effect (Campbell \& Mínguez-Vera, 2007). To control the effect of inverse causality there needs to be an econometric method that can deal with endogeneity and with the presence of unobservable fixed effects that are associated with each company and correlated with the rest of the explanatory variables. To overcome this econometric problem, this study used a panel 2SLS regression technique. In the first step, board ethnic minority is determined by using OLS regression techniques and in the second step, values determined for ethnic minority are used to determine agency costs. The models are formulated using assets utilisation ratio and dividend payout ratio as proxies' proxy for PA and PP agency costs. Therefore, this study estimates following model:

$$
\begin{aligned}
& A C=\beta_{0}+\Sigma \beta_{f} M I N O_{2 t t}+\Sigma \beta_{l} C V_{t t}+\varepsilon_{t t} \\
& M I N O^{n}=\gamma_{0}+\Sigma \gamma_{i} I N S_{j t}+\Sigma \beta_{i} C V_{j t}++\varepsilon_{t i} \\
& A C=\rho_{2}+\Sigma \rho_{z} M I N O_{z t t_{p t}}^{n}+\Sigma \rho_{z} C V_{z t}+s_{t t}
\end{aligned}
$$

Where AC represents firm PA and PP agency costs proxies, MINO represents two alternative variables (MINO and DMINO), and INS represents the instrumental variable for this study, CV represents all control variables.

This study conducted a Breusch-Pagan/Cook-Weisberg test for heteroskedasticity for all regression variables and the results indicate there is no heteroskedasticity is existing in this study sample.

\section{Results}

Table 2 indicates 2SLS regression results for minority directors during times of global financial crisis and non-global financial crisis. Columns 2-5 report PA agency costs results and 6-9 report PP agency costs results. The coefficients of MINO and PMINO variables are negatively and statistically significant at $1 \%$ level for PA agency costs in global financial crisis time and insignificant in a non-global financial crisis. This result indicates minority director percentage has no impact on firm PA agency costs in non-recession time and increases PA agency costs in times of global financial crisis. This finding is also consistent with Foo \& Zain (2010) who explain Malaysian boards with high levels of minority directors increase information asymmetry problems. Further, this finding is consistent with Cox (1991) and Hambrick et al. (1996) who explain diversity within top management brings potential costs to an organisation due to interpersonal conflicts and communication problems. Results confirm this conflict becomes worse in times of financial crisis because an uncertain environment increases communication difficulties and group conflicts. Another possible

\footnotetext{
2 The test statistics have $\mathrm{p}>0.05$ for PA and PP agency costs proxies, so the null hypothesis of no correlation is accepted and random-effects model is appropriate for this study.
} 
explanation is information asymmetry, which has been identified as one of the challenges facing emerging economies (Murray, 2008). In economic turbulent times, this information asymmetry problem can worsen and increase agency costs with heterogeneous top managers. Therefore, PA conflict can be highlighted during economic uncertainty periods with high representation of ethnic monitory directors. When recruiting top managers, it is important to look at the skill base of the team and see how best to complement it. Nevertheless, to achieve "signalling" benefit from investors in economic turbulent times Sri Lankan listed firms increase their ethnic minority directors without considering their skills, experience, or suitability to the company. This increased PA agency costs with ethnic minority directors during the recent economic recession in Sri Lanka. Another possible explanation is the appointment of ethnic minority directors to Sri Lankan boards may express "pork barrel” behaviour. This means, after using political influence to appoint a board director, politicians try to get returns for their political campaign or support from the firm. Politically controlled personal management became widespread in the Sri Lankan economy soon after the end of the civil war in 2009. As politicians keep their power over appointees, the carrier path and incentives for directors (especially ethnic minority directors) of Sri Lankan firms are very much driven by political motivations. This may be another reason for increases in PA agency costs in recent years in Sri Lanka.

Further, results indicate that regardless of economic downturn, large boards increase Sri Lankan listed firms' PA agency costs. This finding is consistent with Jensen (1993) and Lipton \& Lorsch (1992) who suggest that when board size is increased the agency problem positively significantly increases within the board. Due to the high existence of family businesses listed on the CSE (Masulis et al., 2009), the possibility of free-rider problems can increase along with board size. These large boards often move into a more figurative role, rather than fulfilling the intended functions as part of management. Moreover, the OWNER variable is significantly negatively related with PA agency costs' proxy, indicating local ownership increases PA agency conflict. Compared to foreign owned firms, locally owned firms' board recruitment can be biased. Political and family intervention is common in countries with weak legal structures like Sri Lanka. Sri Lanka's central government and its committees are the ultimate authorities over the selection and appointment of board chairpersons and most of the top directors of almost all state-owned listed companies. Therefore, local firms' ethnic minority directors may not be well diversified by way of skills and experience and they reinforce agency conflict in the firms. Interestingly, results show firm debt has a significant negative impact on PA agency conflict in a global financial crisis. This may be because banks closely monitor firms to ensure they operate more efficiently by better utilising assets and limiting perk consumption as the firm attempts to improve its reported financial performance to the bank (Ang et al., 2000).

Table 2 further indicates board minority-director percentage, or the presence of minority directors on a board, does not have significant impact on PP agency costs in a global financial crisis. Tunnelling and expropriation of minority shareholders by majority shareowners is prevalent in emerging markets (Claessens et al., 2000). This study indicates, MINO and DMINO variables have significant negative impact on PP agency costs' proxy in stable 


\section{Macrothink Mnstitute}

economic times, showing 1\% significant negative relationship between firm PP agency costs and minority variables. This indicates board ethnic diversity increases firm monitoring and condenses expropriation and tunnelling of minority shareholders. However, results indicate that board ethnic diversity is only an effective mechanism for mitigating PP agency costs in stable economic times. Finally, results show the OWNER variable shows a 1\% statistically significant negative relationship with PP agency costs.

Table2. Regression results of board ethnic diversity and agency costs

\begin{tabular}{|c|c|c|c|c|c|c|c|c|}
\hline & PA-Financial cri & & PA-Non financial & risis & PP-Financial cris & & PP-Non financial & risis \\
\hline Variable & $\begin{array}{c}\text { Coefficient-OLS } \\
\text { (2) }\end{array}$ & $\begin{array}{c}\text { Coefficient-2SLS } \\
\text { (3) }\end{array}$ & $\begin{array}{c}\text { Coefficient-OLS } \\
\text { (4) }\end{array}$ & $\begin{array}{c}\text { Coefficient-2SLS } \\
\text { (5) }\end{array}$ & $\begin{array}{c}\text { Coefficient-OLS } \\
\text { (6) }\end{array}$ & $\begin{array}{c}\text { Coefficient-2SLS } \\
\text { (7) }\end{array}$ & $\begin{array}{c}\text { Coefficient-OLS } \\
\text { (8) }\end{array}$ & $\begin{array}{c}\text { Coefficient-2SLS } \\
\text { (9) }\end{array}$ \\
\hline Constant & $\begin{array}{l}-.4224061 \\
(.3507244)\end{array}$ & $\begin{array}{l}-.4099763 \\
(.3590398)\end{array}$ & $\begin{array}{l}-.6232533^{* * *} \\
(.184966)\end{array}$ & $\begin{array}{l}-.6265047^{* * *} \\
(.1917891)\end{array}$ & $\begin{array}{l}.6619877 * * \\
(.3293341)\end{array}$ & $\begin{array}{l}.5935541^{* *} \\
(.2967112)\end{array}$ & $\begin{array}{l}.1914518 \\
(.1278533)\end{array}$ & $\begin{array}{l}.1746436 \\
(.1234031)\end{array}$ \\
\hline $\begin{array}{l}\text { \% of } \\
\text { minority } \\
\text { directors } \\
\text { (MINO) }\end{array}$ & $\begin{array}{l}-.3912622^{* *} \\
(.1755619)\end{array}$ & & $\begin{array}{l}.0199208 \\
(.101011)\end{array}$ & & $\begin{array}{l}-.4498976 \\
(.3456206)\end{array}$ & & $\begin{array}{l}-.2671727 * * \\
(.1277529)\end{array}$ & \\
\hline $\begin{array}{l}\text { Presence of } \\
\text { minority } \\
\text { directors } \\
\text { (DMINO) }\end{array}$ & & $\begin{array}{l}-.2897845 * * \\
(-.2897845)\end{array}$ & & $\begin{array}{l}.0365868 \\
(.1857347)\end{array}$ & & $\begin{array}{l}-.2249264 \\
(.1691991)\end{array}$ & & $\begin{array}{l}-.145774 * * \\
(.0689892)\end{array}$ \\
\hline $\begin{array}{l}\text { Board size } \\
\text { (BOARD) }\end{array}$ & $\begin{array}{l}-.0410255^{*} \\
(.0242427) \\
\end{array}$ & $\begin{array}{l}-.0393689 \\
(.0243185)\end{array}$ & $\begin{array}{l}-.0406893 * * * \\
(.0127133)\end{array}$ & $\begin{array}{l}-.0406385^{* * *} \\
(.012713)\end{array}$ & $\begin{array}{l}.0000766 \\
(.0196331) \\
\end{array}$ & $\begin{array}{l}.0021207 \\
(.0191457) \\
\end{array}$ & $\begin{array}{l}-.0052758 \\
(.0086517)\end{array}$ & $\begin{array}{l}-.004816 \\
(.0085743)\end{array}$ \\
\hline $\begin{array}{l}\text { Leverage } \\
\text { (DEBT) }\end{array}$ & $\begin{array}{l}.0046207^{* *} \\
(.0025959) \\
\end{array}$ & $\begin{array}{l}.0049334^{* *} \\
(.0026583) \\
\end{array}$ & $\begin{array}{l}.0020466 \\
(.0013286) \\
\end{array}$ & $\begin{array}{l}.0020696 \\
(.0013089) \\
\end{array}$ & $\begin{array}{l}-.0026878 \\
(.0022387)\end{array}$ & $\begin{array}{l}-.0028111 \\
(.002158) \\
\end{array}$ & $\begin{array}{l}-.0010945 \\
(.0009004)\end{array}$ & $\begin{array}{l}-.0009293 \\
(.0009054) \\
\end{array}$ \\
\hline $\begin{array}{l}\text { Firm Size } \\
\text { (LNSALES) }\end{array}$ & $\begin{array}{l}.1321207^{* * *} \\
(.0240225) \\
\end{array}$ & $\begin{array}{l}.137823^{* * *} \\
(.0241171) \\
\end{array}$ & $\begin{array}{l}.1360854^{* * *} \\
(.0121676) \\
\end{array}$ & $\begin{array}{l}.1364697^{* * *} \\
(.0120956) \\
\end{array}$ & $\begin{array}{l}-.0164613 \\
(.0195401) \\
\end{array}$ & $\begin{array}{l}-.0109039 \\
(.0190178) \\
\end{array}$ & $\begin{array}{l}.0084938 \\
(.008052) \\
\end{array}$ & $\begin{array}{l}.0107882 \\
(.0080462) \\
\end{array}$ \\
\hline $\begin{array}{l}\text { Performance } \\
\text { (ROA) }\end{array}$ & $\begin{array}{l}.1777375 \\
(.6084797) \\
\end{array}$ & $\begin{array}{l}.0501268 \\
(.6154137) \\
\end{array}$ & $\begin{array}{l}.44723 \\
(.3491161) \\
\end{array}$ & $\begin{array}{l}.4349182 \\
(.341048) \\
\end{array}$ & $\begin{array}{l}.2947512 \\
(.4912113) \\
\end{array}$ & $\begin{array}{l}.2011843 \\
(.487951) \\
\end{array}$ & $\begin{array}{l}.2819799 \\
(.2343633) \\
\end{array}$ & $\begin{array}{l}.1869511 \\
(.2379057) \\
\end{array}$ \\
\hline $\begin{array}{l}\text { Local } \\
\text { ownership } \\
\text { (OWNER) }\end{array}$ & $\begin{array}{l}-.2378569 * * \\
(.0961501)\end{array}$ & $\begin{array}{l}-.2555889 * \\
(.0990612)\end{array}$ & $\begin{array}{l}-.1788843^{* * *} \\
(.0512415)\end{array}$ & $\begin{array}{l}-.1783686^{* * *} \\
(.0512415)\end{array}$ & $\begin{array}{l}-.1479504 * \\
(.0819049)\end{array}$ & $\begin{array}{l}-.1495568 * * \\
(.0806333)\end{array}$ & $\begin{array}{l}-.1054102 * * * \\
(.0358384)\end{array}$ & $\begin{array}{l}-.1021027^{* * *} \\
(.0348608)\end{array}$ \\
\hline $\begin{array}{l}\text { Firm age } \\
\text { (AGE) }\end{array}$ & $\begin{array}{l}.0772082 \\
(.0659737) \\
\end{array}$ & $\begin{array}{l}.071145 \\
(.0661754)\end{array}$ & $\begin{array}{l}-.1270228 * * * \\
(.0504975)\end{array}$ & $\begin{array}{l}-.1261209 * \\
(.050798) \\
\end{array}$ & $\begin{array}{l}.0196904 \\
(.0534401) \\
\end{array}$ & $\begin{array}{l}.0265202 \\
(.0520977) \\
\end{array}$ & $\begin{array}{l}.0972349 * * * \\
(.034544)\end{array}$ & $\begin{array}{l}.1031176^{* * *} \\
(.0340567)\end{array}$ \\
\hline $\begin{array}{l}\text { Regression } \\
\text { summary } \\
F \\
R^{2} \\
\end{array}$ & $\begin{array}{l}10.74 \\
(0.000) \\
0.2016 \\
\end{array}$ & $\begin{array}{l}20.35 \\
(0.000) \\
0.1875 \\
\end{array}$ & $\begin{array}{l}15.68 \\
(0.000) \\
0.1750 \\
\end{array}$ & $\begin{array}{l}18.75 \\
(0.000) \\
0.2101\end{array}$ & $\begin{array}{l}11.13 \\
(0.000) \\
0.3841 \\
\end{array}$ & $\begin{array}{l}19.31 \\
(0.000) \\
0.2139 \\
\end{array}$ & $\begin{array}{l}16.69 \\
(0.000) \\
0.7400\end{array}$ & $\begin{array}{l}11.03 \\
(0.000) \\
0.3885 \\
\end{array}$ \\
\hline
\end{tabular}

* Significant at $10 \%$ level; **Significant at 5\% level; ***Significant at $1 \%$ level; This model provides standard errors which are in parentheses

\section{Conclusion and Implications}

This study offers new insights into the relationship between board ethnic diversification and agency costs in a Sri Lankan context. Approximately $40 \%$ of Sri Lankan listed board members are from ethnic minorities. The recent global financial crisis is one reason for recruiting more ethnic minorities on to corporate boards in Sri Lanka. Though ethnic diversification adds value to Sri Lankan firms in financial stable times, this study indicates board ethnic diversity increases agency conflict during times of high financial uncertainty, such as a global financial crisis. 
The reason for the high percentage of ethnic minority directors on Sri Lankan boards may be due to restructuring or downsizing of firms during an economic; firms try to keep low paid ethnic minority directors rather than highly paid ethnic majority directors. Ethnic minority directors may only increase number of ethnic minority representation and not be effective in the company. Moreover, especially in global financial crisis, external governance bodies and stakeholders are more likely to consider board diversity. Ideally, board diversity should increase the talent and skills of the board. However, most probably, board members are selected from personal or political contacts of the CEO or other board directors (Langevoort, 2011). This is prevalent in emerging markets. Therefore the recruiting process needs to be more transparent and consideration given to any potential director's knowledge and appropriateness for the company.

As a country with many ethnic minorities, it is required to have some social programmes in place to reduce the effect of being minority in a social group. It can decrease boundary heightening and exaggeration by dominants emphasis the difference between minority and majority in work places. This leads to a reduction in negative workplace experiences for minority groups, helps to reduce the "token" experience of minority directors and hence improves monitoring and reduces agency conflicts.

As a country with mostly family businesses on their stock exchange, managers and top leaders require training. Vocational training institutions that target geographical areas where there are more ethnic minority groups can increase minority directors' management ability in Sri Lanka. This is the best solution for skill mismatching. Then boards can recruit qualified minority directors.

Although a positive relationship between ethnic minority in the boardroom and firm performance is often cited in the previous literature and popular press, this study shows environmental uncertainty creates costs when adding more ethnic minority board members. An efficient board may be able to balance the costs and benefits of ethnic diversification. This balance would depend on the institutional environment and market conditions. Therefore, the actual relationship between board ethnic diversity and firm performance is still unsolved.

\section{References}

Adams, R. B., \& Ferreira, D. (2002). Diversity and incentives in teams: evidence from corporate boards, Working Paper: Federal Reserve Bank of New York.

Ang, J. S., Cole, R. A., \& Wuh, L. J. (2000). Agency costs and ownership structure. The Journal of Finance, LV(1), 81-106. http://dx.doi.org/10.1111/0022-1082.00201

Arrow, K. J. (1951). Social Choice and Individual Values (2nd ed. 1963 ed.). New York, NY: John Wiley.

. (2011). 'Corporate Governance '. Board Diversity: Calstrs.

. (2009). 'Boards in Turbulent Times'. Heidrick \& Struggles.

Borensztein, E., \& Lee, J. W. (2002). Financial Crisis and Credit Crunch: Evidence form the 
Korean Firm Level Data. Journal of Monetary Economics, 49(4), 853-875. http://dx.doi.org/10.1016/S0304-3932(02)00116-2

Brammer, S., Millington, A., \& Pavelin, S. (2007). Gender and Ethnic Diversity Among UK $\begin{array}{llll}\text { Corporate } \quad \text { Boards. } & \text { Corporate } & \text { Governance, }\end{array}$ http://dx.doi.org/10.1111/j.1467-8683.2007.00569.x

Claessens, S, S Djankov and L Lang. 2000. "The separation of ownership and control in East Asian corporations." Journal of Financial Economics 58:81-112. http://dx.doi.org/10.1016/S0304-405X(00)00067-2

Campbell, K., \& Mínguez-Vera, A. (2007). Gender Diversity in the Boardroom and Firm Financial Performance Journal of Business Ethics, 83(3).

Carno, W. D., \& Chen, X. (1998). The leniency contract and persistence of majority and minority influence. Journal of Personality and Social Psychology, 74, 1437-1452.

http://dx.doi.org/10.1037/0022-3514.74.6.1437

Carter, D. A., Simkins, B. J., \& Simpson, W. G. (2003). Corporate Governance, Board Diversity, and Firm Value. Financial Review, 38, 33-53. http://dx.doi.org/10.1111/1540-6288.00034

Chrisman, J. J., Chua, J. H., \& Litz, R. A. (2004). Comparing the Agency Costs of Family and Non-Family Firms: Conceptual Issues and Exploratory Evidence. Entrepreneurship Theory and Practice, 28(4), 335-354. http://dx.doi.org/10.1111/j.1540-6520.2004.00049.x

Colombage, S. R. (2007). Consistency and controversy in corporate financing practices: Evidence from an emerging market. Studies in Economics and Finance, 24(1), 51-71. http://dx.doi.org/10.1108/10867370710737382

Cox, T. (1991). The multicultural organization. Academy of Management Executive, 5(2), 34-47.

Davidson, M. (Ed.). (2002). The Black and Ethnic Minority Woman Manager (Vol. 53-66). Oxford: Blackwell.

DeAngelo, H. L., \& Skinner, D. (2004). Are dividends disappearing? Dividend concentration and the consolidation of earnings growth. Journal of Financial Economics, 72, 425-456. http://dx.doi.org/10.1016/S0304-405X(03)00186-7.

Erhardt, N. L., Werbel, J. D., \& Schrader, C. B. (2003). Board of director diversity and firm financial performance. Corporate Governance, 11, 102-111. http://dx.doi.org/10.1111/1467-8683.00011

Faccio, M., Lang, L., \& Young, L. (2001). Dividends and expropriation. American Economic Review 91(1), 54-78. http://dx.doi.org/10.1257/aer.91.1.54

Farrell, K., \& Hersch, P. (2005). Additions to Corporate Boards: The Effect of Gender. Journal of Corporate Finance, 11, 85-106. http://dx.doi.org/10.1016/j.jcorpfin.2003.12.001 
Fields, M. (2011). Diversity Plays a Role in Surviving the Economic Downturn.

Foo, Y. B., \& Zain, M. M. (2010). Do Board Characteristics affect Information Asymmetry? Evidence from Malaysia.

Frances, J., \& LMartins. (1996). Searching for Common Threads: Understanding the Multiple Effects of Diversity in Organizational Groups. The Academy of Management Review, 21.

Gomez, E. T., \& Jomo, K. S. (1997). Malaysia's Political Economy: Politics, patronage, and profits. Cambridge: Cambridge University Press.

Gregoric, A., Oxelheim, L., Randoy, T., \& Thomsen, S. (2009). Corporate governance as a source of competitiveness for Nordic firms: Nordic Innovation Centre.

Hambrick, D. C., Cho, T. S., \& Chen, M. J. (1996). The influence of top management team heterogeneity on firms' competitive moves. Administrative Science Quarterly, 41, 659-684. http://dx.doi.org/10.2307/2393871

Haniffa, R. M., \& Cooke, T. E. (2002). Culture, corporate governance, and disclosure in Malaysian corporations. Abacus, 38(3), 317-349. http://dx.doi.org/10.1111/1467-6281.00112

Hill, E. (2004). Taking Diversity to the Next Level in Tough Times: Knowledge@Emory.

Hoffman, L. R., \& Maier, N. R. F. (1961). Quality and Acceptance of Problem Solutions by Members of Homogeneous and Heterogeneous Groups. Journal of Abnormal and Social Psychology, 62, 401-407. http://dx.doi.org/10.1037/h0044025

Hot Topics. (2011). Corporate Governance Trends -Looking Back as We Move Forward: Deloitte Development LLC.

Jensen, M., \& Meckling, W. H. (1976). Theory of the firm: Managerial behaviour, agency costs, and ownership structure. Journal of Financial Economics, 3, 305-360.

Jensen, M. C. (1993). The Modern Industrial Revolution, Exit and the Failure of Internal Control Systems. Journal of Finance, 48(3), 831-880. http://dx.doi.org/10.2307/2329018

John, K., \& Knyazeva, A. (2006). Pay-out policy, agency conflicts and corporate governance, working paper: New York University. Pay-out policy, agency conflicts and corporate governance.

Johnson, S., \& Mitton, T. (2003). Cronyism and capital controls: evidence from Malaysia. Journal of Financial Economics, 351-338. http://dx.doi.org/10.1016/S0304-405X(02)00255-6

Kanter, R. M. (1977). Men and women of the corporation. New York: Basic Books.

Langevoort, D. C. (2011). Commentary: Puzzles about Corporate Boards and Board Diversity North Carolina Law Review, 89.

Laughlin, P. R. (1992). Influence and Performance in Simultaneous collective and individual induction. Organisational Behaviour and Human Decision 51, 447-470. 
http://dx.doi.org/10.1016/0749-5978(92)90021-X

Lipton, M., \& Lorsch, J. W. (1992). A Modest Proposal for Improved Corporate Governance. Business Lawyer, 48(1), 59-77.

Macfarlane, F., Sinhuber, D., \& Khan, T. (2010). Diversity Briefing: The Canadian Institute of Chartered Accountants.

Madalla, G.S., 2001. Introduction to Econometrics, New York: Wiley

Marimuthu, M. (2008). Ethnic Diversity on Boards of Directors and Its Implications of Firm Financial Performance. Journal of International Social Research, 1(4), 432-445.

Masulis, R W, P K Pham and J Zein. 2009. Family Business groups around the World: Costs and Benefits of Pyramids.

Mattis, M. C. (Ed.). (2000). Women Corporate Directors in the United States: Kluwer Academic: Netherlands.

Murray, J.E. (2008) "Identifying, Separating, and Managing Asymmetric Information in Early 20c Health Insurance"

Rathnayake, J. (2009). The global financial crisis like the downside, SL to feel recovery late. http://www.tisrilanka.org/?p=2793

Renaud, B. (2003). Speculative behaviour in immature real estate markets, lessons of the 1997 Asia financial crisis Urban Policy and Research, 21(2), 153-173. http://dx.doi.org/10.1080/08111140309950

Reskin, B. F., McBrier, D. B., \& Kmec, J. A. (1999). The determinants and consequences of workplace sex and race composition. Annual Review of Sociology, 335-361. http://dx.doi.org/10.1146/annurev.soc.25.1.335

Roberson, Q., \& Park, H. (2007). Examining the Link Between Diversity and Firm Performance: The Effects of Diversity Reputation and Leader Racial Diversity. Group \& Organization Management, 32, 548-568. http://dx.doi.org/10.1177/1059601106291124

Ross, S. A. (1973). The Economic Theory of Agency: The Principal's Problem.

Singh, M., \& Davidson, W. N. (2003). Agency costs, ownership structure and corporate governance mechanisms. Journal of Banking and Finance, 27, 793-816. http://dx.doi.org/10.1016/S0378-4266(01)00260-6

Spencer, S. J., Steele, C. M., \& Quinn, D. M. (1999). Stereotype threat and women's math performance. , 35,. Journal of Experimental Social Psychology, 35, 4-28. http://dx.doi.org/10.1006/jesp.1998.1373

Steele, C. M., \& Aronson, J. (1995). Stereotype threat and the intellectual test performance of African-Americans. Journal of Personality and Social Psychology, 69, 797-811. http://dx.doi.org/10.1037/0022-3514.69.5.797 
Villalonga, B., \& Amit, R. (2006). How do family ownership, control and management affect firm value? Journal of Financial Economics, 80, 385-417. http://dx.doi.org/10.1016/j.jfineco.2004.12.005

Wang, Y., \& Clift, B. (2009). Is There a "Business Case" for Board Diversity? Pacific Accounting Review, 21, 88. http://dx.doi.org/10.1108/01140580911002044

Yatim, P., Kent, P., \& Clarkson, P. (2006). Governance Structures, Ethnicity, and Audit Fees of Malaysian Listed Firms.

Zander, A. (1979). The psychology of group processes. Annual Review of Psychology, 30, 417-451. http://dx.doi.org/10.1146/annurev.ps.30.020179.002221 